\title{
Correction to: A Functional CLT for Partial Traces of Random Matrices
}

\author{
Jan Nagel ${ }^{1}$ \\ Published online: 19 October 2021 \\ (c) The Author(s) 2021
}

\section{Correction to: Journal of Theoretical Probability (2021) 34:953-974 https://doi.org/10.1007/s10959-019-00982-1}

The article "A Functional CLT for Partial Traces of Random Matrices", written by Jan Nagel1, was originally published electronically on the publisher's internet portal on 20 January 2020 without open access. With the author(s)' decision to opt for Open Choice, the copyright of the article changed on 22 September 2021 to $@$ The Author(s) 2020 and the article is forthwith distributed under a Creative Commons Attribution 4.0 International License, which permits use, sharing, adaptation, distribution and reproduction in any medium or format, as long as you give appropriate credit to the original author(s) and the source, provide a link to the Creative Commons licence, and indicate if changes were made. The images or other third party material in this article are included in the article's Creative Commons licence, unless indicated otherwise in a credit line to the material. If material is not included in the article's Creative Commons licence and your intended use is not permitted by statutory regulation or exceeds the permitted use, you will need to obtain permission directly from the copyright holder. To view a copy of this licence, visit http://creativecommons.org/licenses/by/4.0.

The original article has been corrected.

Open Access This article is licensed under a Creative Commons Attribution 4.0 International License, which permits use, sharing, adaptation, distribution and reproduction in any medium or format, as long as you give appropriate credit to the original author(s) and the source, provide a link to the Creative Commons licence, and indicate if changes were made. The images or other third party material in this article are included in the article's Creative Commons licence, unless indicated otherwise in a credit line to the material. If material is not included in the article's Creative Commons licence and your intended use is not permitted by statutory regulation or exceeds the permitted use, you will need to obtain permission directly from the copyright holder. To view a copy of this licence, visit http://creativecommons.org/licenses/by/4.0/.

The original article can be found online at https://doi.org/10.1007/s10959-019-00982-1.

$凶 \quad$ Jan Nagel

jan.nagel@tu-dortmund.de

1 Fakultät Für Mathematik, TU Dortmund, Vogelpothsweg 87, 44227 Dortmund, Germany 
Funding Open Access funding enabled and organized by Projekt DEAL.

Publisher's Note Springer Nature remains neutral with regard to jurisdictional claims in published maps and institutional affiliations. 